\title{
Kecerdasan Emosional, Kecerdasan Intelektual dan Kecerdasan Spiritual Terhadap Pemahaman Akuntansi Dasar Dengan Motivasi Sebagai Variabel Moderating
}

\author{
Fitri Nuraini \\ Fakultas Ekonomi, Universitas Muhammadiyah Surabaya, Indonesia \\ Email: ftr_account@yahoo.co.id
}

\begin{abstract}
Abstrak
Akuntansi dasar sangatlah penting sebagai awal memahami konsep akuntansi, apabila pada dasar saja belum bisa memahami sepenuhnya maka untuk selanjutnya juga terasa sulit. Konsep pengantar akuntansi sangatlah penting terutama bagi mahasiswa baru, ibarat bangunan atau rumah maka pengantar akuntansi merupakan pondasinya. Penelitian ini menguji pengaruh kecerdasan emosional, kecerdasan intelektual dan kecerdasan spiritual terhadap pemahaman akuntansi dasar dengan motivasi sebagai variabel moderating. Dalam kaitannya dengan variabel moderating, peneliti dalam hal ini memilih motivasi sebagai pemoderasi hubungan antara kecerdasan emosional, kecerdasan intelektual dan kecerdasan spiritual dengan pemahaman akuntansi dasar. Populasi yang digunakan dalam penelitian ini adalah 104 mahasiswa prodi akuntansi semester 1 dan 3 Universitas Muhammadiyah Surabaya. Teknik sampling menggunakan convenience sampling dengan pengambilan sampel sebesar 77. Penelitian menggunakan alat analisis Moderated Regression Analysis (MRA). Hasil penelitian menunjukan bahwa (1) kecerdasan emosional dan kecerdasan spiritual berpengaruh tidak signifikan terhadap pemahaman akuntansi dasar, (2) kecerdasan intelektual berpengaruh signifikan terhadap pemahaman akuntansi dasar, (3) motivasi tidak memoderasi pengaruh kecerdasan emosional, kecerdasan intelektual dan kecerdasan spiritual terhadap pemahaman akuntansi dasar.
\end{abstract}

Kata kunci : kecerdasan emosional, kecerdasan intelektual, kecerdasan spiritual, motivasi, pemahaman terhadap akuntansi dasar.

\begin{abstract}
Basic accounting is very important as the beginning to understand the concept of accounting, if on the basis of it can not fully understand then for the next is also difficult. The concept of introduction accounting is very important, especially for new students, like a building or a house then introduction accounting is the foundation. This study examines the effect of emotional intelligence, intellectual intelligence and spiritual intelligence on basic accounting comprehension with motivation as a moderating variable. In relation to moderating variables, researchers in this case choose motivation as a moderator of the relationship between emotional intelligence, intellectual intelligence and spiritual intelligence with basic accounting comprehension. The population used in this study was 104 students of Accounting Study Program in Semester 1 and 3 of Muhammadiyah University of Surabaya. The sampling technique uses convenience sampling with sampling of 77. The study used Moderated Regression Analysis (MRA) analysis tool. The result of research shows that (1) emotional intelligence and spiritual intelligence have an insignificant effect on basic accounting comprehension, (2) intellectual intelligence has significant effect on basic accounting
\end{abstract}


comprehension, (3) motivation does not moderate the influence of emotional intelligence, intellectual intelligence and spiritual intelligence toward understanding of accounting basic.

Keywords: emotional intelligence, intellectual, spiritual intelligence, motivation, understanding of basic accounting

\section{Pendahuluan}

"Akuntansi merupakan suatu sistem dengan input data/informasi dan output berupa informasi dan laporan keuangan yang bermanfaat bagi pengguna internal dan eksternal entitas" (Martani dkk; 2016). Dan program studi studi akuntansi lumayan banyak diminati oleh masyarakat, hal ini ditunjukkan dengan peluang pekerjaan yang menjanjikan misalnya akuntan perusahaan, akuntan pendidik, akuntan public, akuntan pemerintah. Pendidikan akuntansi yang diselenggarakan oleh perguruan tinggi bertujuan untuk mendidik mahasiswa agar dapat bekerja sebagai akuntan professional yang memiliki kompetensi dibidang ilmu akuntansi. Untuk menghasilkan lulusan akuntan yang berkualitas dan mampu bersaing maka perguruan tinggi harus lebih meningkatkan kualitas mutu pendidikannya. Mahasiswa tidak hanya diberikan materi secara teori saja tetapi disertai konsep akuntansi dan perbanyak latihan soal. Akuntasi bukanlah ilmu yang menghafal seperti menghafal rumus matematika, kimia maupun fisika tetapi lebih menggunakan penalaran yang membutuhkan logika. Menghafal tidak menjamin mahasiswa memahami akuntansi.

Akuntansi dasar sangatlah penting sebagai awal memahami konsep akuntansi, apabila pada dasar saja belum bisa memahami sepenuhnya maka untuk selanjutnya juga terasa sulit. Untuk akuntansi dasar pada perguruan tinggi pada matakuliah pengantar akuntansi. Pengantar Akuntansi merupakan matakuliah yang menjelaskan konsep akuntansi yang termasuk analisis transaksi dan siklus akuntansi untuk perusahaan jasa, dagang dan industri. Konsep pengantar akuntansi sangatlah penting terutama bagi mahasiswa baru, ibarat bangunan atau rumah maka pengantar akuntansi merupakan pondasinya. Dinamakan pondasi haruslah kuat dan kokoh untuk menopang bangunan atau rumah diatasnya. Diharapkan dengan memahami pengantar akuntansi akan memberikan kemudahan untuk akuntansi selanjutnya yaitu akuntansi keuangan menengah, akuntansi keuangan lanjutan dan pemeriksaan akuntansi.

Secara umum tingkat pemahaman seseorang terhadap suatu ilmu pengetahuan baru dipengaruhi oleh kecerdasan, dan kecerdasan dikelompokkan menjadi 3 (tiga) 
yang antara lain kecerdasan emosional, kecerdasan intelektual dan kecerdasan spiritual. Seperti yang dinyatakan oleh Goleman (2000) bahwa "kemampuan akademik bawaan, nilai rapor, dan prediksi kelulusan dari pendidikan tinggi tidak dapat memprediksi seberapa baik kinerja seseorang sudah bekerja atau seberapa tinggi sukses yang dicapainya dalam hidup". Kecerdasan Emosional mampu melatih kemampuan mahasiswa yaitu kemampuan mengelola perasaan, kemampuan memotivasi diri, kesanggupan tegar dalam menghadapi masalah/frustasi, kesanggupan mengendalikan dorongan dan menunda kepuasan sesaat, mengatur suasana hati yang reaktif, serta mampu berempati dan bekerja sama dengan orang lain. Dengan kecerdasan emosional dapat membentuk kepribadian dan emosi seseorang tetapi tidak mudah dalam membentuk pribadi dengan kecerdasan emosional yang ideal, sehingga perlu kesabaran.

Selain kecerdasan emosional sebagai faktor dalam mempengaruhi pemahaman mahasiswa akan akuntansi dasar maka terdapat faktor lain yang tentunya juga mempunyai pengaruh yaitu kecerdasan intelektual dan kecerdasan spiritual. Kecerdasan intelektual merupakan kemampuan intelektual, analisa, logika dan rasio. Seseorang dengan kecerdasan intelektual yang baik, tidak ada baginya memperoleh informasi yang sulit, semuanya dapat disimpan dan diolah. Proses kecerdasan intelektual yaitu dapat diartikan proses dalam menerima, menyimpan, dan mengolah kembali informasi atau biasa disebut berfikir. Berfikir adalah media untuk menambah perbendaharaan dalam otak manusia.

Selanjutnya orang yang memiliki kecerdasan spiritual (SQ) akan mampu menyelesaikan permasalahan yang dihadapinya dengan melihat permasalahan itu dari nilai positif sehingga permasalahan dapat diselesaikan dengan baik. Kecerdasan spiritual (SQ) terlihat pada aktivitas sehari-hari, seperti bagaimana cara mengambil keputusan, memahami makna kehidupan dan menjadi orang bijaksana. Memiliki kecerdasan spiritual (SQ) juga berarti memiliki kemampuan sikap fleksibility, mudah menyesuaikan diri, mampu mengambil hikmah dari setiap kejadian. (http://www.gelombangotak.com/Pengertian-Kecerdasan-Spiritual\%20(SQ).htm)

Menurut Agustian (2007) "kecerdasan spiritual merupakan kemampuan memberi makna spiritual terhadap pemikiran, perilaku dan kegiatan serta dapat menyinergikan $I Q, E Q$ dan $S Q$ secara bersama-sama". Prinsip-prinsip kecerdasan spiritual menurut Agustian (2007) antara lain "prinsip bintang, prinsip malaikat 
(kepercayaan), prinsip kepemimpinan, prinsip pembelajaran, prinsip masa depan dan prinsip keteraturan". Dan barangkali perbedaan yang paling penting diketahui antara $I Q$ dan $E Q$ adalah $E Q$ tidak dipengaruhi oleh faktor keturunan .

Kecerdasan intelektual (IQ) lebih bersifat permanen, dan kecerdasan emosional $(E Q)$ justru memungkinkan untuk dipelajari kapanpun dan siapapun yang mempunyai keinginan untuk meraih sukses. Selanjutnya untuk kecerdasan spiritual dengan sikap yang tenang, berfikir positif, dan menyelesaikan secara bijaksana. Berusaha mengembangkan potensi yang dimiliki dengan upaya belajar (learning to do, learning to know) (IQ), learning to be (SQ), dan learning to live together (EQ), memperbaiki kualitas diri pribadi, sampai diperoleh aktualisasi diri merupakan tantangan dalam kehidupan. Tugas perwujudan diri sebagai pendidik yang professional yakni berusaha memotivasi,mendidik peserta didik untuk dapat mengembangkan potensi yang dimiliki, melalui proses pembelajaran yang bermakna (Meaningful Learning) (SQ), menyenangkan (Joyful Learning) (EQ), dan penuh tantangan/hambatan (Problematical Learning) (IQ).

Proses belajar mengajar berkaitan dengan kecerdasan emosional, kecerdasan intelektual dan kecerdasan spiritual mahasiswa. Dengan kecerdasan emosional mampu melatih kemampuan mahasiswa, yaitu kemampuan mengelola emosi dalam berinteraksi dengan orang lain. Dalam memahami akuntansi dasar adanya kecerdasan intelektual juga merupakan hal yang penting untuk dipertimbangkan, mampu menerima, menyimpan dan mengolah kembali informasi yang diperoleh. Dan dengan kecerdasan spiritual yakni memiliki keinginan untuk berusaha berubah menjadi orang yang lebih baik , berfikir positif serta dapat menyelesaikan masalah dengan bijaksana.

Kenyataannya berdasarkan pengalaman peneliti, mayoritas mahasiswa semester 1 dan 3 di universitas Muhammadiyah Surabaya masih belum memahami mengenai akuntansi dasar yaitu pengantar akuntansi, hal ini kurangnya latihan soal, mahasiswa hanya belajar dikelas saja. Referensi buku hanya dimiliki beberapa mahasiswa, kurangnya kesadaran mahasiswa untuk berusaha memiliki buku. Untuk itu diharapkan mahasiswa bisa menggali ilmu mengenai akuntansi dasar dari sumber lain, misalnya browsing internet, membaca atau meminjam buku diperpustakaan, mengikuti kursus akuntansi. Dan itu semua memerlukan kemampuan dalam berfikir dan 
berhubungan dengan orang lain sehingga terjadi keseimbangan cerdas antara emosi, akal dan ketenangan hati.

Pada penelitian ini akan menguji pengaruh kecerdasan emosional, kecerdasan intelektual dan kecerdasan spiritual terhadap pemahaman akuntansi dasar dengan motivasi sebagai variabel moderating. Peneliti dalam hal ini memilih motivasi sebagai variabel moderating yakni pemoderasi hubungan antara kecerdasan emosional, kecerdasan intelektual dan kecerdasan spiritual dengan pemahaman akuntansi dasar. Peneliti juga memilih motivasi sebagai variabel moderating karena motivasi terbentuk sikap kesadaran diri dalam pemahaman pentingnya belajar untuk memperoleh ilmu pengetahuan (http://www.AnneAhira.com, 2010).

Menurut Handoko (2011) adanya "teori kebutuhan menurut Maslow dalam konsep motivasi belajar bahwa dengan motivasi yang kuat akan semakin kuat juga dalam mempengaruhi perilaku seseorang untuk mempelajari dan memahami akuntansi dasar". Teori yang pertama tentang kebutuhan dasar, dihubungkan dengan fisik dan psikologis. Seseorang akan ada motivasi belajar yang kuat jika tidak diimbangi dengan makanan \& minuman serta psikologis yang bagus. Teori kedua tentang kebutuhan tumbuh, hal ini berkaitan dengan adanya kebutuhan untuk mengetahui dan memahami, keindahan dan aktualisasi diri.

Melalui 2 teori kebutuhan, maka dapat diketahui faktor - faktor kondisional apa saja yang berperan dalam memperkuat atau memperlemah hubungan antara kecerdasan emosional, kecerdasan intelektual dan kecerdasan spiritual terhadap pemahaman mahasiswa akuntansi semester 1 dan 3 tentang akuntansi dasar, dalam hal ini motivasi bisa merupakan salah satu faktor kondisional yang berperan dalam memperkuat atau memperlemah hubungan antara kecerdasan emosional, kecerdasan intelektual dan kecerdasan spiritual terhadap pemahaman mahasiswa akuntansi semester 1 dan 3 tentang akuntansi dasar. Berdasarkan teori kebutuhan tersebut, penelitian ini mencoba untuk menguji hubungan tidak langsung antara kecerdasan emosional, kecerdasan intelektual dan kecerdasan spiritual dengan pemahaman mahasiswa akuntansi semester 1 dan 3 tentang akuntansi dasar dengan memasukkan variabel motivasi sebagai variabel pemoderasi.

Objek dalam penelitian ini mahasiswa akuntansi semester 1 dan 3 yang masih aktif di Universitas Muhammadiyah Surabaya. Alasan obyek penelitian mahasiswa 
semester 1 dan 3 dikarenakan nantinya mereka akan memperoleh matakuliah akuntansi keuangan menengah, yang konsep dasarnya diperoleh dari akuntansi dasar yaitu pengantar akuntansi.

Sebelumnya penelitian yang pernah dilakukan terkait dengan kecerdasan emosional, kecerdasan intelektual dan kecerdasan spiritual serta pemahaman akuntansi dasar adalah Yuniani (2010), Zakiah (2013), dan Pasek (2015) yang menunjukkan bahwa "tingkat pemahaman materi akuntansi sebagai tolak ukur kemampuan seorang/calon akuntan baik dari pendidikan sekolah, perguruan tinggi maupun instansi, dengan demikian penelitian yang berfokus pemahaman akuntansi dasar yaitu pengantar akuntansi ini ditekankan pada pengaruh kecerdasan emosional, kecerdasan intelektual dan kecerdasan spiritual dengan motivasi sebagai moderating".

Perbedaannya dengan penelitian terdahulu sebagian besar berfokus pada pemahaman akuntansi, sehingga peneliti lebih memfokuskan pada pemahaman akuntansi dasar yaitu pengantar akuntansi. Keputusan ini diambil berdasarkan pada pendapat bahwa dengan motivasi akan mampu memperkuat pengaruh kecerdasan emosional, kecerdasan intelektual dan kecerdasan spiritual terhadap pemahaman akuntansi dasar. Seseorang yang memiliki motivasi yang tinggi terhadap akuntansi dasar cenderung lebih aktif dalam menggali informasi mengenai akuntansi dasar dibandingkan tidak memiliki motivasi terhadap akuntansi dasar.

Tujuan penelitian dalam penyusunan penelitian ini adalah untuk menganalisa pengaruh kecerdasan emosional, kecerdasan intelektual dan kecerdasan spiritual terhadap pemahaman akuntansi dasar dengan motivasi sebagai variabel moderating.

\section{Kerangka Konseptual}

Kerangka pemikiran dalam penelitian ini adalah :

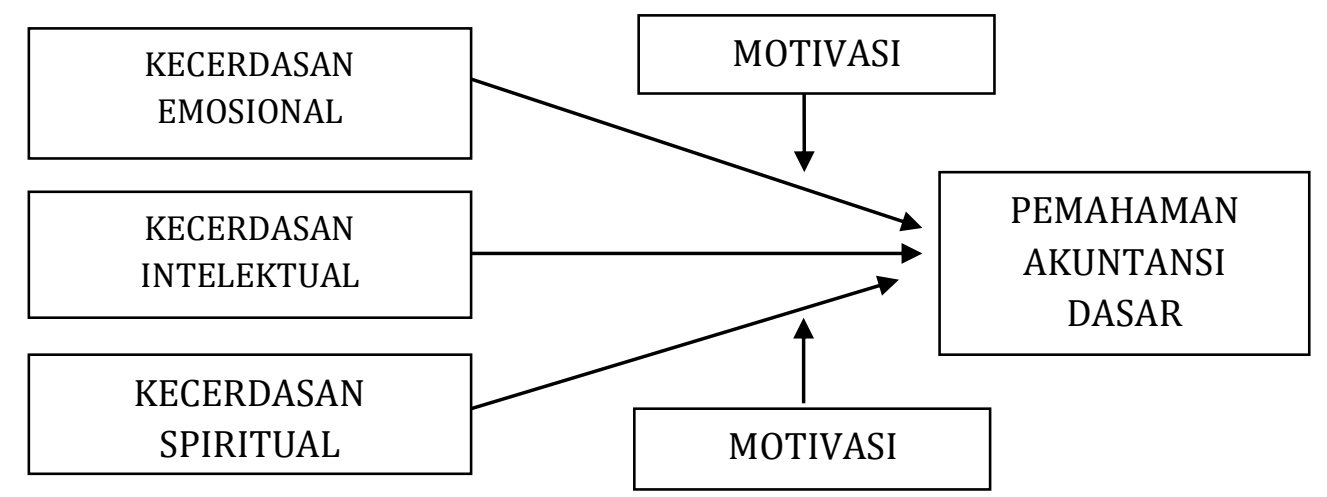




\section{Hipotesis}

H1 : Kecerdasan Emosional Berpengaruh Secara Signifikan Terhadap Pemahaman Mahasiswa Mengenai Akuntansi Dasar.

H2 : Kecerdasan Intelektual Berpengaruh Secara Signifikan Terhadap Pemahaman Mahasiswa Mengenai Akuntansi Dasar.

H3 : Kecerdasan Spiritual Berpengaruh Secara Signifikan Terhadap Pemahaman Mahasiswa Mengenai Akuntansi Dasar.

H4a : Motivasi Memoderasi Pengaruh Kecerdasan Emosional Mahasiswa Terhadap Pemahaman Akuntansi Dasar.

H4b : Motivasi Memoderasi Pengaruh Kecerdasan Intelektual Mahasiswa Terhadap Pemahaman Akuntansi Dasar.

H4c : Motivasi Memoderasi Pengaruh Kecerdasan Spiritual Mahasiswa Terhadap Pemahaman Akuntansi Dasar.

\section{Metode Penelitian}

\section{Jenis Penelitian dan Sumber Data}

Jenis penelitian ini adalah penelitian kuantitatif menggunakan data primer dan sekunder ,untuk data primer dengan teknik pengumpulan data melalui kuesioner yaitu dengan cara memberikan kuesioner kepada 104 mahasiswa yang masih aktif dalam perkuliahan di Universitas Muhammadiyah Surabaya. Dan data sekunder diperoleh dari bagian Dikjar Fakultas Ekonomi Universitas Muhammadiyah Surabaya dan keterangan lain yang berkaitan dengan data yang dibutuhkan.

\section{Populasi dan sampel}

Objek penelitian ini adalah Universitas Muhammadiyah Surabaya, populasinya adalah mahasiswa Fakultas Ekonomi program studi akuntansi semester I angkatan 2016 sebanyak 60 mahasiswa dan semester III angkatan 2015 sebanyak 44 mahasiswa. Dengan jumlah sampel keseluruahn sebanyak 104 mahasiswa

Sampel ditentukan dengan teknik convenience sampling yang bersifat nonprobabilistik. Ukuran sampel yang dibutuhkan dalam penelitian ini diperoleh dari rumus Slovin (Umar, 2004) dengan formula sebagai berikut : 
$\mathrm{n}$

$$
=\frac{\mathrm{N}}{1+\mathrm{Ne}^{2}}
$$

Dimana :

$$
\begin{array}{ll}
\mathrm{n} & =\text { Ukuran sampel } \\
\mathrm{N} & =\text { Ukuran populasi } \\
\mathrm{e} & =\text { Persen kelonggaran ketidaktelitian karena kesalahan pengambilan sampel } \\
& \text { yang masih dapat ditolerir atau diinginkan. }
\end{array}
$$

Maka :

$$
\mathrm{n}=\frac{104}{1+(104)(0.1)^{2}}=50.9804
$$

Dibulatkan menjadi 51 responden, sehingga dalam penelitian ini jumlah sampel yang dibutuhkan paling sedikit 51 responden.

\section{Pengukuran Variabel}

\section{Kecerdasan Emosional $\left(\mathrm{X}_{1}\right)$}

Kecerdasan emosional adalah kemampuan mengenali perasaan sendiri dan orang lain, kemampuan memotivasi diri sendiri, kemampuan mengolah emosi dengan baik. Variabel kecerdasan emosional diukur dengan menggunakan indikator yang dikembangkan oleh Melandy dan Aziza (2006) dan diuji dengan 5 (lima) butir pernyataan yaitu Pengenalan diri (self awareness), Pengendalian diri (self regulation), Motivasi (motivation), Empati (emphathy), dan Ketrampilan social (social skills).

\section{Kecerdasan Intelektual $\left(\mathrm{X}_{2}\right)$}

Variabel kecerdasan intelektual diukur dengan menggunakan indikator yang dikembangkan oleh Dwijayanti (2009) dan diuji dengan 3 (tiga) pernyataan mengenai kemampuan memecahkan masalah, intelegensi verbal, dan intelegensi praktis.

\section{Kecerdasan Spiritual $\left(\mathrm{X}_{3}\right)$}

Variabel kecerdasan spiritual diukur dengan menggunakan indikator yang dikembangkan oleh Zakiah (2013) dan diuji dengan 9 (sembilan) pernyataan mengenai bersikap fleksibel, kesadaran diri, menghadapi dan memanfaatkan penderitaan, menghadapi dan melampaui perasaan sakit, keengganan untuk menyebabkan kerugian, kualitas hidup, berpandangan holistic, kecenderungan bertanya, dan bidang mandiri.

\section{Motivasi $\left(\mathrm{X}_{4}\right)$}


Motivasi dalam penelitihan ini adalah sebagai variabel moderating. Motivasi yang digunakan adalah motivasi terhadap pengetahuan mengenai akuntansi dasar. Motivasi terhadap akuntansi dasar ini diukur dari seberapa besar keinginan individu dalam mempelajari dan mencari informasi mengenai akuntansi dasar. Variabel ini diukur dengan indikator menurut teori Maslow dan diuji dengan 2 (2) butir pernyataan mengenai (1) kebutuhan dasar meliputi kebutuhan fisiologis; kebutuhan akan rasa aman; kebutuhan untuk dicintai; kebutuhan untuk dihargai ; dan (2) kebutuhan tumbuh, yang terdiri dari: kebutuhan untuk mengetahui dan memahami; kebutuhan keindahan; kebutuhan aktualisasi diri.

\section{Pemahaman Akuntansi Dasar (Y)}

Kemampuan mahasiswa dalam memahami dan mengerti mengenai akuntansi dasar dan dinyatakan dalam bentuk kuisioner. Satuan pengukuran yang digunakan untuk variabel bebas dan terikat adalah skala Semantic Defferensial. Berikut bobot nilai jawaban kuisioner sebagai berikut :

Sangat Setuju Setuju Tidak Setuju Sangat Tidak Setuju

4 3

2 1

Sumber: Sugiyono, 2012

\section{Teknik Pengujian Hipotesis}

\section{Uji Validitas}

Sebuah instrumen memiliki validitas tinggi jika butir-butir yang membentuk instrumen tidak menyimpang dari fungsi instrumen tersebut. Menurut Ghozali $(2013,53)$ syarat minimum agar suatu butir dapat dianggap valid jika diperoleh nilai $r$ hitung $>r$ table.

\section{Uji Reliabilitas}

Uji reliabilitas ini menggunakan reliabilitas konsistensi internal yaitu teknik cronbach Alpha $(\alpha)$." Apabila nilai cronbach Alpha dari hasil pengujian > 0.70 maka dapat dikatakan bahwa konstruk atau variabel itu adalah reliable" (Ghozali : 2013,48).

\section{Uji Normalitas}

Uji normalitas digunakan untuk mengetahui apakah suatu data mengikuti sebaran normal atau tidak dengan menggunakan metode Kolmogrov Smirnov dan metode Shapiro Wilk. Menurut Sumarsono (2007) pedoman dalam mengambil 
keputusan, apakah sebuah distribusi data mengikuti distribusi normal jika nilai signifikan atau nilai probabilitas $>0,05$.

\section{Teknik Analisis dan Uji Hipotesis}

Pengujian terhadap hipotesis dilakukan dengan menggunakan uji statistik $\mathrm{f}$ dan t, yaitu pengujian koefisien untuk mengetahui pengaruh baik secara simultan maupun parsial dari setiap variabel independen terhadap variabel dependennya. Dan untuk menguji pengaruh variabel moderasi digunakan MRA (Moderated Regression Analysis) dengan rumus persamaan regresi :

$$
\begin{array}{ll}
\mathrm{Y} & =\mathrm{a}+\mathrm{b}_{1} \mathrm{X}_{1}+\mathrm{b}_{2} \mathrm{X}_{2}+\mathrm{b}_{3} \mathrm{X}_{3}+\mathrm{b}_{4} \mathrm{X}_{4}+\mathrm{b}_{5}\left|\mathrm{X}_{1}-\mathrm{X}_{4}\right|+\mathrm{e} \\
\mathrm{Y} & =\mathrm{a}+\mathrm{b}_{1} \mathrm{X}_{1}+\mathrm{b}_{2} \mathrm{X}_{2}+\mathrm{b}_{3} \mathrm{X}_{3}+\mathrm{b}_{4} \mathrm{X}_{4}+\mathrm{b}_{5}\left|\mathrm{X}_{2}-\mathrm{X}_{4}\right|+\mathrm{e} \\
\mathrm{Y} & =\mathrm{a}+\mathrm{b}_{1} \mathrm{X}_{1}+\mathrm{b}_{2} \mathrm{X}_{2}+\mathrm{b}_{3} \mathrm{X}_{3}+\mathrm{b}_{4} \mathrm{X}_{4}+\mathrm{b}_{5}\left|\mathrm{X}_{3}-\mathrm{X}_{4}\right|+\mathrm{e}
\end{array}
$$

\section{Hasil dan Pembahasan}

Kuisioner yang disebarkan sebanyak 104 kuisioner dari mahasiswa prodi akuntansi semester 1 dan 3 Universitas Muhammadiyah Surabaya. Penyebaran kuesioner dilakukan pada waktu pelaksanaan UAS (Ujian Akhir Semester). Dan setelah dilakukan pengeditan data dan persiapan untuk pengolahan, 27 kuisioner diputuskan tidak digunakan dalam analisa karena pengisian kuisioner kurang lengkap dan form kuesioner kurang. Gambaran selengkapnya mengenai proses penyebaran dan penerimaan kuisioner dapat dilihat pada tabel berikut:

Tabel 1

Gambaran Proses Penyebaran dan Penerimaan Kuisioner

\begin{tabular}{ll}
\hline Keterangan & Jumlah Kuisioner \\
\hline Kuisioner yang disebar & 104 \\
Kuisioner yang diterima & 77 \\
Kuisioner yang tidak digunakan/diolah & 27 \\
Prosentase & $100 \%$ \\
Kuisioner yang valid & 77 \\
\hline Prosentase & $74.03 \%$ \\
\hline
\end{tabular}

\section{Sumber : Data diolah}

Berdasarkan data yang diperoleh dari 77 responden, berikut ini dipaparkan mengenai jumlah responden berdasarkan semester. Berikut ini deskripsi gambaran responden yaitu mahasiswa prodi akuntansi semester 1 dan 3 Universitas Muhammadiyah Surabaya yang aktif dalam perkuliahan. 
Tabel 2.

Berdasarkan Semester

\begin{tabular}{|l|l|l|l|}
\hline No. & Semester & Jumlah & Prosentase (\%) \\
\hline 1. & I (satu) & 52 & 68 \\
\hline 2. & III (tiga) & 25 & 32 \\
\hline Jumlah & 77 & 100 \\
\hline
\end{tabular}

\section{Sumber : Data diolah}

Pada tabel 2 menunjukkan bahwa responden berasal dari mahasiswa prodi akuntansi semester 1 Universitas Muhammadiyah Surabaya yaitu 68\%. Hal ini dikarenakan jumlah mahasiswa prodi akuntansi Tahun Akademik 2016/2017 mengalami kenaikan dari Tahun Akademik sebelumnya.

\section{Uji Analisis Data}

\section{Uji Validitas}

Hasil uji validitas untuk variabel kecerdasan emosional (X1), kecerdasan intelektual (X2), kecerdasan spiritual (X3) dan motivasi (X4) dan pemahaman akuntansi dasar (Y) dapat dilihat dari tabel-tabel dibawah ini :

\section{Hasil Uji Validitas Kecerdasan Emosional (X1)}

Tabel 3.

Hasil Uji Validitas Variabel Kecerdasan Emosional ( $\mathrm{X}_{1}$ )

\begin{tabular}{|l|l|l|l|}
\hline Pernyataan & $\begin{array}{l}\text { Koefisien } \\
\text { korelasi }(\mathrm{r})\end{array}$ & Nilai r tabel & Penilaian \\
\hline $\mathrm{X} 1-1$ & 0.520 & 0.224 & Valid \\
\hline $\mathrm{X} 1-2$ & 0.557 & 0.224 & Valid \\
\hline $\mathrm{X} 1-3$ & 0.605 & 0.224 & Valid \\
\hline $\mathrm{X} 1-4$ & 0.559 & 0.224 & Valid \\
\hline $\mathrm{X} 1-5$ & 0.490 & 0.224 & Valid \\
\hline $\mathrm{X} 1-6$ & 0.436 & 0.224 & Valid \\
\hline $\mathrm{X} 1-7$ & 0.634 & 0.224 & Valid \\
\hline $\mathrm{X} 1-8$ & 0.539 & 0.224 & Valid \\
\hline $\mathrm{X} 1-9$ & 0.514 & 0.224 & Valid \\
\hline $\mathrm{X} 1-10$ & 0.557 & 0.224 & Valid \\
\hline $\mathrm{X} 1-11$ & 0.645 & 0.224 & Valid \\
\hline $\mathrm{X} 1-12$ & 0.570 & 0.224 & Valid \\
\hline $\mathrm{X} 1-13$ & 0.632 & 0.224 & Valid \\
\hline $\mathrm{X} 1-14$ & 0.698 & 0.224 & Valid \\
\hline $\mathrm{X} 1-15$ & 0.594 & 0.224 & Valid \\
\hline $\mathrm{X} 1-16$ & 0.576 & 0.224 & Valid \\
\hline $\mathrm{X} 1-17$ & 0.557 & 0.224 & Valid \\
\hline $\mathrm{X} 1-18$ & 0.633 & 0.224 & Valid \\
\hline $\mathrm{X} 1-19$ & 0.673 & 0.224 & Valid \\
\hline $\mathrm{X} 1-20$ & 0.742 & 0.224 & Valid \\
\hline
\end{tabular}




\begin{tabular}{|l|l|l|l|}
\hline Pernyataan & $\begin{array}{l}\text { Koefisien } \\
\text { korelasi }(\mathrm{r})\end{array}$ & Nilai r tabel & Penilaian \\
\hline $\mathrm{X} 1-21$ & 0.676 & 0.224 & Valid \\
\hline $\mathrm{X} 1-22$ & 0.596 & 0.224 & Valid \\
\hline
\end{tabular}

\section{Sumber : Data diolah}

Berdasarkan hasil uji validitas terhadap 22 pernyataan yang terdapat di dalam kuisioner yang disebarkan kepada mahasiswa prodi akuntansi semester 1 dan 3 diperoleh nilai

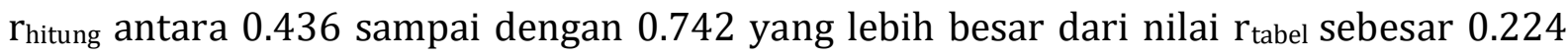
sehingga 22 pernyataan dianggap valid.

\section{Hasil Uji Validitas Kecerdasan Intelektual (X2)}

Tabel 4.

Hasil Uji Validitas Variabel Kecerdasan Intelektual $\left(\mathrm{X}_{2}\right)$

\begin{tabular}{|l|l|l|l|}
\hline Pernyataan & $\begin{array}{l}\text { Koefisien } \\
\text { korelasi }(\mathrm{r})\end{array}$ & Nilai r tabel & Penilaian \\
\hline $\mathrm{X} 2-1$ & 0.664 & 0.224 & Valid \\
\hline $\mathrm{X} 2-2$ & 0.799 & 0.224 & Valid \\
\hline $\mathrm{X} 2-3$ & 0.703 & 0.224 & Valid \\
\hline $\mathrm{X} 2-4$ & 0.745 & 0.224 & Valid \\
\hline $\mathrm{X} 2-5$ & 0.725 & 0.224 & Valid \\
\hline $\mathrm{X} 2-6$ & 0.719 & 0.224 & Valid \\
\hline $\mathrm{X} 2-7$ & 0.656 & 0.224 & Valid \\
\hline $\mathrm{X} 2-8$ & 0.734 & 0.224 & Valid \\
\hline $\mathrm{X} 2-9$ & 0.711 & 0.224 & Valid \\
\hline $\mathrm{X} 2-10$ & 0.633 & 0.224 & Valid \\
\hline
\end{tabular}

\section{Sumber : Data diolah}

Berdasarkan hasil uji validitas terhadap 10 pernyataan yang terdapat di dalam kuisioner yang disebarkan kepada mahasiswa prodi akuntansi semester 1 dan 3 diperoleh nilai $r_{\text {hitung }}$ antara 0.633 sampai dengan 0.799 yang lebih besar dari nilai $r_{\text {tabel }}$ sebesar 0.224 sehingga 10 pernyataan dianggap valid.

\section{Hasil Uji Validitas Kecerdasan Spiritual (X3)}

Tabel 5.

Hasil Uji Validitas Variabel Kecerdasan Spiritual $\left(\mathrm{X}_{3}\right)$

\begin{tabular}{|l|l|l|l|}
\hline Pernyataan & $\begin{array}{l}\text { Koefisien } \\
\text { korelasi (r) }\end{array}$ & Nilai r tabel & Penilaian \\
\hline X3-1 & 0.644 & 0.224 & Valid \\
\hline X3-2 & 0.662 & 0.224 & Valid \\
\hline X3-3 & 0.654 & 0.224 & Valid \\
\hline X3-4 & 0.677 & 0.224 & Valid \\
\hline X3-5 & 0.680 & 0.224 & Valid \\
\hline X3-6 & 0.636 & 0.224 & Valid \\
\hline
\end{tabular}




\begin{tabular}{|l|l|l|l|}
\hline Pernyataan & $\begin{array}{l}\text { Koefisien } \\
\text { korelasi }(\mathrm{r})\end{array}$ & Nilai $\mathrm{r}$ tabel & Penilaian \\
\hline X3-7 & 0.539 & 0.224 & Valid \\
\hline X3-8 & 0.672 & 0.224 & Valid \\
\hline X3-9 & 0.530 & 0.224 & Valid \\
\hline X3-10 & 0.648 & 0.224 & Valid \\
\hline X3-11 & 0.711 & 0.224 & Valid \\
\hline X3-12 & 0.688 & 0.224 & Valid \\
\hline X3-13 & 0.667 & 0.224 & Valid \\
\hline
\end{tabular}

\section{Sumber : Data diolah}

Berdasarkan hasil uji validitas terhadap 13 pernyataan yang terdapat di dalam kuisioner yang disebarkan kepada mahasiswa prodi akuntansi semester 1 dan 3 diperoleh nilai $\mathrm{r}_{\text {hitung }}$ antara 0.530 sampai dengan 0.711 yang lebih besar dari nilai $r_{\text {tabel }}$ sebesar 0.224 sehingga 13 pernyataan dianggap valid.

\section{Hasil Uji Validitas Motivasi (X4)}

Tabel 6.

Hasil Uji Validitas 1 Variabel Motivasi $\left(\mathrm{X}_{4}\right)$

\begin{tabular}{|l|l|l|l|}
\hline Pernyataan & $\begin{array}{l}\text { Koefisien } \\
\text { korelasi }(\mathrm{r})\end{array}$ & Nilai r tabel & Penilaian \\
\hline $\mathrm{X} 4-1$ & 0.791 & 0.224 & Valid \\
\hline $\mathrm{X} 4-2$ & 0.458 & 0.224 & Valid \\
\hline $\mathrm{X} 4-3$ & 0.793 & 0.224 & Valid \\
\hline $\mathrm{X} 4-4$ & 0.787 & 0.224 & Valid \\
\hline $\mathrm{X} 4-5$ & 0.800 & 0.224 & Valid \\
\hline $\mathrm{X} 4-6$ & 0.818 & 0.224 & Valid \\
\hline $\mathrm{X} 4-7$ & 0.793 & 0.224 & Valid \\
\hline $\mathrm{X} 4-8$ & 0.834 & 0.224 & Valid \\
\hline $\mathrm{X} 4-9$ & 0.822 & 0.224 & Valid \\
\hline $\mathrm{X} 4-10$ & 0.660 & 0.224 & Valid \\
\hline $\mathrm{X} 4-11$ & 0.627 & 0.224 & Valid \\
\hline $\mathrm{X} 4-12$ & 0.154 & 0.224 & Tidak Valid \\
\hline
\end{tabular}

\section{Sumber : Data diolah}

Berdasarkan hasil uji validitas terhadap 12 pernyataan yang terdapat di dalam kuisioner yang disebarkan kepada mahasiswa prodi akuntansi semester 1 dan 3 diperoleh nilai

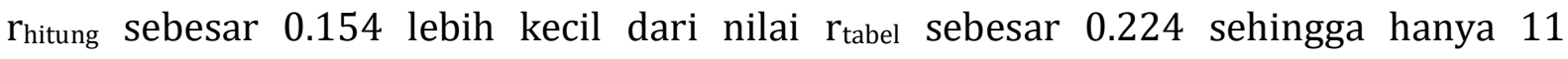
pernyataan dianggap valid sisanya tidak valid. Dan dilakukan uji validitas kedua sehingga data yang disajikan memenuhi kriteria valid yaitu $>0.224$. 
Tabel 7

Hasil Uji Validitas 2 Variabel Motivasi $\left(\mathrm{X}_{4}\right)$

\begin{tabular}{|l|l|l|l|}
\hline Pernyataan & $\begin{array}{l}\text { Koefisien } \\
\text { korelasi }(\mathrm{r})\end{array}$ & Nilai r tabel & Penilaian \\
\hline $\mathrm{X} 4-1$ & 0.791 & 0.224 & Valid \\
\hline $\mathrm{X} 4-2$ & 0.458 & 0.224 & Valid \\
\hline $\mathrm{X} 4-3$ & 0.793 & 0.224 & Valid \\
\hline $\mathrm{X} 4-4$ & 0.787 & 0.224 & Valid \\
\hline $\mathrm{X} 4-5$ & 0.800 & 0.224 & Valid \\
\hline $\mathrm{X} 4-6$ & 0.818 & 0.224 & Valid \\
\hline $\mathrm{X} 4-7$ & 0.793 & 0.224 & Valid \\
\hline $\mathrm{X} 4-8$ & 0.834 & 0.224 & Valid \\
\hline $\mathrm{X} 4-9$ & 0.822 & 0.224 & Valid \\
\hline $\mathrm{X} 4-10$ & 0.660 & 0.224 & Valid \\
\hline $\mathrm{X} 4-11$ & 0.627 & 0.224 & Valid \\
\hline Sumber & & & \\
\hline
\end{tabular}

Sumber : Data diolah

\section{Hasil Uji Validitas Pemahaman Akuntansi Dasar (Y)}

Tabel 8.

Hasil Uji Validitas Variabel Pemahaman Akuntansi Dasar (Y)

\begin{tabular}{|l|l|l|l|}
\hline Pernyataan & $\begin{array}{l}\text { Koefisien } \\
\text { korelasi }(\mathrm{r})\end{array}$ & Nilai r tabel & Penilaian \\
\hline Y-1 & 0.686 & 0.224 & Valid \\
\hline Y -2 & 0.817 & 0.224 & Valid \\
\hline Y -3 & 0.759 & 0.224 & Valid \\
\hline Y -4 & 0.819 & 0.224 & Valid \\
\hline Y -5 & 0.806 & 0.224 & Valid \\
\hline Y -6 & 0.830 & 0.224 & Valid \\
\hline Y -7 & 0.769 & 0.224 & Valid \\
\hline Y -8 & 0.776 & 0.224 & Valid \\
\hline Y -9 & 0.738 & 0.224 & Valid \\
\hline Y -10 & 0.751 & 0.224 & Valid \\
\hline Y -11 & 0.789 & 0.224 & Valid \\
\hline Y -12 & 0.836 & 0.224 & Valid \\
\hline
\end{tabular}

Berdasarkan hasil uji validitas terhadap 12 pernyataan yang terdapat di dalam

kuisioner yang disebarkan kepada mahasiswa prodi akuntansi semester 1 dan 3 diperoleh nilai $r_{\text {hitung }}$ antara 0.686 sampai dengan 0.836 yang lebih besar dari nilai $r_{\text {tabel }}$ sebesar 0.224 sehingga 12 pernyataan dianggap valid.

\section{Uji Reliabilitas}

Hasil uji reliabilitas pada variabel bebas dan terikat dapat dilihat pada tabel di bawah ini : 
Tabel 9.

Uji Reliabilitas

\begin{tabular}{|l|l|l|}
\hline Variabel & R Alpha & Hasil \\
\hline Pemahaman Akuntansi Dasar $(\mathrm{Y})$ & 0.951 & Reliabel \\
\hline Kecerdasan Emosional $\left(\mathrm{X}_{1}\right)$ & 0.914 & Reliabel \\
\hline Kecerdasan Intelektual $\left(\mathrm{X}_{2}\right)$ & 0.889 & Reliabel \\
\hline Kecerdasan Spiritual $\left(\mathrm{X}_{3}\right)$ & 0.898 & Reliabel \\
\hline Motivasi $\left(\mathrm{X}_{4}\right)$ & 0.907 & Reliabel \\
\hline
\end{tabular}

\section{Sumber : Data diolah}

Hasil uji reliabilitas dari variabel bebas dan terikat diatas menunjukan nilai yang lebih dari 0,70 sehingga dapat disimpulkan bahwa seluruh variabel dalam penelitian ini adalah reliabel.

\section{Uji Normalitas}

Hasil uji normalitas untuk variabel tingkat pemahaman terhadap IFRS (Y), kecerdasan emosional $\left(\mathrm{X}_{1}\right)$, kecerdasan intelektual $\left(\mathrm{X}_{2}\right)$, kecerdasan spiritual $\left(\mathrm{X}_{3}\right)$ dan motivasi $\left(\mathrm{X}_{4}\right)$ dapat dilihat pada gambar normal graph histogram di bawah ini :

\section{Gambar 1 \\ Diagram normal graph histogram}
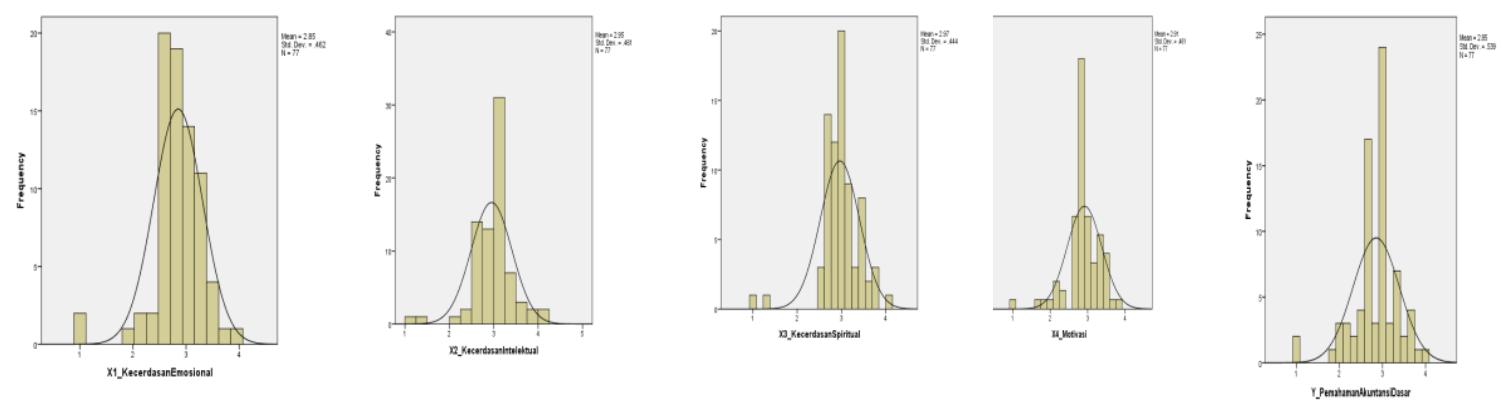

\section{Sumber : Data diolah}

Hasil uji normalitas ini pertama menggunakan Kolmogorov Smirnov tetapi hasil ujinya hanya tiga variabel yang berdistribusi normal, karena tingkat signifikan yang dihasilkan diatas 5\%. Dan dua variabel lainnya berdistribusi tidak normal.Untuk itu peneliti menggunakan alternatif uji normalitas yang lain yaitu dengan gambar normal graph histogram yang menunjukkan bahwa data masing-masing variabel membentuk lengkung seperti lonceng, hal tersebut beraarti asumsi normalitas semua variabel terpenuhi. Kriteria pengujian yaitu jika lengkung membentuk seperti lonceng maka kecederungan data berditribusi normal. Jika lengkung tidak membentuk seperti lonceng maka kecederungan data berdistribusi tidak normal.

\section{Analisis Pengujian Asumsi Klasik}




\section{Pengujian Multikolinier}

Identifikasi ada atau tidaknya gejala multikolinier dilakukan dengan menghitung Variance Inflation Factor (VIF). Nilai VIF untuk masing-masing variabel diatas bahwa nilai VIF seluruh variabel bebas dan variabel moderating lebih kecil dari 10, artinya kedua variabel bebas dan satu variabel moderating pada penelitian ini tidak ada gejala multikolinier.

\section{Pengujian Heterokedastisitas}

Uji heteroskedastisitas bertujuan menguji apakah dalam model regresi terjadi ketidaksamaan variance dari residual satu pengamatan ke pengamatan yang lain. Hal tersebut dapat dilihat pada hasil pengujian output nonparametric correlations diketahui bahwa masing-masing variabel bebas dan variabel moderating berada diatas signifikan $5 \%$. Ini berarti variabel bebas dan variabel moderating pada penelitian ini tidak ada gejala heteroskedastisitas.

\section{Persamaan Analisis Regresi Moderating}

Persamaan analisis regresi moderating dengan model nilai selisih mutlak sebagai berikut :

$Y=0.576+0.015 X_{1}+0.484 X_{2}-0.199 X_{3}+0.510 X_{4}-0.137\left(X_{1}-X_{4}\right)$

$\mathrm{Y}=0.375+0.036 \mathrm{X}_{1}+0.534 \mathrm{X}_{2}-0.234 \mathrm{X}_{3}+0.499 \mathrm{X}_{4}+0.060\left(\mathrm{X}_{2}-\mathrm{X}_{4}\right)$

$Y=0.392+0.027 X_{1}+0.527 X_{2}-0.225 X_{3}+0.508 X_{4}+0.031\left(X_{3}-X_{4}\right)$

\section{Pengujian Hipotesis}

Hasil uji hipotesis pada penelitian ini terdapat dua analisis dan dua uji hipotesis adalah sebagai berikut :

\section{Pengaruh Kecerdasan Emosional Terhadap Pemahaman Akuntansi Dasar Dengan} Motivasi sebagai Variabel Moderating.

Tabel 10.

Hasi uji F (ANOVA)

\begin{tabular}{|l|l|l|l|l|l|}
\hline Sumber varian & \multicolumn{1}{|c|}{$\begin{array}{c}\text { Jumlah } \\
\text { kuadrat }\end{array}$} & \multicolumn{1}{|c|}{ Df } & $\begin{array}{c}\text { Kuadrat } \\
\text { tengah }\end{array}$ & \multicolumn{1}{|c|}{ F hitung } & Sig. \\
\hline Regresi & 10.345 & 5 & 2.069 & 12.553 & 0.000 \\
\hline Sisa & 11.702 & 71 & .165 & & \\
\hline Total & 22.047 & 76 & & & \\
\hline
\end{tabular}

\section{Sumber : Data diolah}

Berdasarkan tabel diatas dapat diketahui nilai $\mathrm{F}$ hitung yang diperoleh dari pengolahan data adalah 12.553 dengan tingkat siginifikansi sebesar 0,000 atau lebih 
kecil 0.05 maka Ho ditolak dengan Ha diterima, yang artinya model yang digunakan adalah signifikan atau cocok untuk mengetahui pengaruh kecerdasan emosional $\left(\mathrm{X}_{1}\right)$, kecerdasan intelektual $\left(\mathrm{X}_{2}\right)$, kecerdasan spiritual $\left(\mathrm{X}_{3}\right)$ dan motivasi $\left(\mathrm{X}_{4}\right)$ terhadap pemahaman akuntansi dasar ( $\mathrm{Y}$ ).

Uji t dapat digunakan untuk mengetahui signifikan atau tidaknya pengaruh secara parsial kecerdasan emosional $\left(\mathrm{X}_{1}\right)$, kecerdasan intelektual $\left(\mathrm{X}_{2}\right)$, kecerdasan spiritual $\left(\mathrm{X}_{3}\right)$ dan motivasi $\left(\mathrm{X}_{4}\right)$ terhadap pemahaman akuntansi dasar $(\mathrm{Y})$.

Tabel 11.

Hasil uji t

\begin{tabular}{|c|c|c|c|c|}
\hline Variabel & t hitung & Signifikansi & Kriteria Pengujian & Kesimpulan \\
\hline $\begin{array}{l}\text { Kecerdasan } \\
\text { Emosional }\left(\mathrm{X}_{1}\right)\end{array}$ & 0.108 & 0.915 & \multirow{5}{*}{$\begin{array}{l}\text { Jika nilai probabilitas } \\
\text { (P value)/signifikan > } \\
0.05 \text { maka Ho diterima } \\
\text { dan Ha ditolak } \\
\text { Jika nilai probabilitas } \\
\text { (P value)/signifikan < } \\
0.05 \text { maka Ho ditolak } \\
\text { dan Ha diterima }\end{array}$} & $\begin{array}{l}\text { Ho diterima dan } \\
\text { Ha ditolak }\end{array}$ \\
\hline $\begin{array}{l}\text { Kecerdasan } \\
\text { Intelektual } \\
\left(\mathrm{X}_{2}\right)\end{array}$ & 2.885 & 0.005 & & $\begin{array}{l}\text { Ho ditolak dan } \mathrm{Ha} \\
\text { diterima }\end{array}$ \\
\hline $\begin{array}{l}\text { Kecerdasan } \\
\text { Spiritual }\left(X_{3}\right)\end{array}$ & -1.062 & 0.292 & & $\begin{array}{l}\text { Ho diterima dan } \\
\text { Ha ditolak }\end{array}$ \\
\hline Motivasi $\left(\mathrm{X}_{4}\right)$ & 3.383 & 0.001 & & $\begin{array}{l}\text { Ho ditolak dan } \mathrm{Ha} \\
\text { diterima }\end{array}$ \\
\hline $\begin{array}{l}\text { Interaksi } \\
\text { antara } \\
\text { variabel } \\
\text { Kecerdasan } \\
\text { Emosional dan } \\
\text { Motivasi } \\
\left(\mathrm{X}_{1} \mathrm{X}_{4}\right) \\
\end{array}$ & -1.719 & 0.090 & & $\begin{array}{l}\text { Ho diterima dan } \\
\text { Ha ditolak }\end{array}$ \\
\hline
\end{tabular}

\section{Sumber : Data diolah}

Hasil uji t menunjukkan bahwa variabel kecerdasan emosional $\left(\mathrm{X}_{1}\right)$, berpengaruh tidak signifikan terhadap pemahaman mahasiswa prodi akuntansi semester 1 dan 3 Universitas Muhammadiyah Surabaya mengenai akuntansi dasar. Hal ini ditunjukkan

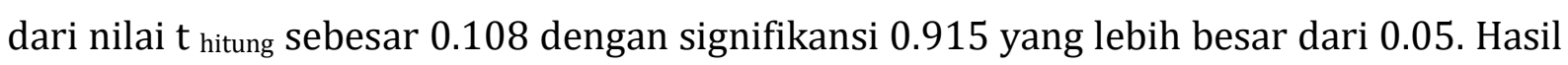
uji $\mathrm{t}$ berikutnya menunjukkan bahwa terdapat pengaruh signifikan kecerdasan intelektual $\left(\mathrm{X}_{2}\right)$ terhadap pemahaman akuntansi dasar. Hal tersebut ditunjukkan dari

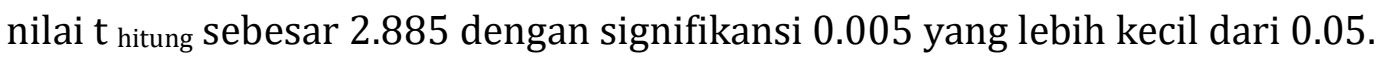

Hasil uji $\mathrm{t}$ juga menunjukkan bahwa variabel kecerdasan spiritual $\left(\mathrm{X}_{3}\right)$, berpengaruh tidak signifikan terhadap pemahaman mahasiswa prodi akuntansi semester 1 dan 3 Universitas Muhammadiyah Surabaya mengenai akuntansi dasar. Hal ini ditunjukkan dari nilai $t$ hitung sebesar -1.062 dengan signifikansi 0.292 yang lebih 
besar dari 0.05. Untuk hasil uji t menunjukan pula bahwa motivasi tidak memoderasi pengaruh kecerdasan emosional terhadap pemahaman akuntansi dasar. Hal ini ditunjukan dari dari nilai $\mathrm{t}$ hitung sebesar -1.719 dengan signifikansi 0.090 yang lebih besar dari 0.05. Tetapi dtunjukkan pada tabel diatas bahwa motivasi mempunyai pengaruh terhadap pemahaman akuntansi dasar jika sebagai variabel bebas bukan sebagai variabel moderating dengan nilai $t$ hitung sebesar 3.383 dan signifikansi 0.001 yang lebih kecil dari 0.05 .

\section{Pengaruh Kecerdasan Intelektual Terhadap Pemahaman Akuntansi Dasar Dengan} Motivasi sebagai Variabel Moderating.

Tabel 12.

Hasi uji F (ANOVA)

\begin{tabular}{|l|l|l|l|l|l|}
\hline Sumber varian & \multicolumn{1}{|c|}{$\begin{array}{c}\text { Jumlah } \\
\text { kuadrat }\end{array}$} & \multicolumn{1}{|c|}{ Df } & $\begin{array}{c}\text { Kuadrat } \\
\text { tengah }\end{array}$ & \multicolumn{1}{|c|}{ F hitung } & Sig. \\
\hline Regresi & 9.931 & 5 & 1.986 & 11.639 & $.000^{\mathrm{b}}$ \\
\hline Sisa & 12.116 & 71 & 0.171 & & \\
\hline Total & 22.047 & 76 & & & \\
\hline
\end{tabular}

\section{Sumber : Data diolah}

Berdasarkan tabel diatas dapat diketahui nilai $\mathrm{F}$ hitung yang diperoleh dari pengolahan data adalah 11.639 dengan tingkat siginifikansi sebesar 0,000 atau lebih kecil 0.05 maka Ho ditolak dengan Ha diterima, yang artinya model yang digunakan adalah signifikan atau cocok untuk mengetahui pengaruh kecerdasan emosional $\left(\mathrm{X}_{1}\right)$, kecerdasan intelektual $\left(\mathrm{X}_{2}\right)$, kecerdasan spiritual $\left(\mathrm{X}_{3}\right)$ dan motivasi $\left(\mathrm{X}_{4}\right)$ terhadap pemahaman akuntansi dasar (Y).

Tabel 13.

Hasil uji t

\begin{tabular}{|c|c|c|c|c|}
\hline Variabel & thitung & Signifikansi & Kriteria Pengujian & Kesimpulan \\
\hline $\begin{array}{l}\text { Kecerdasan } \\
\text { Emosional } \\
\left(\mathrm{X}_{1}\right)\end{array}$ & 0.251 & 0.803 & \multirow{5}{*}{$\begin{array}{l}\text { Jika nilai probabilitas } \\
\text { (P value)/signifikan > } \\
0.05 \text { maka Ho } \\
\text { diterima dan Ha } \\
\text { ditolak } \\
\text { Jika nilai probabilitas } \\
\text { (P value)/signifikan < } \\
0.05 \text { maka Ho ditolak } \\
\text { dan Ha diterima }\end{array}$} & $\begin{array}{l}\text { Ho diterima dan } \mathrm{Ha} \\
\text { ditolak }\end{array}$ \\
\hline $\begin{array}{l}\text { Kecerdasan } \\
\text { Intelektual } \\
\left(\mathrm{X}_{2}\right)\end{array}$ & 3.146 & 0.002 & & $\begin{array}{l}\text { Ho ditolak dan } \mathrm{Ha} \\
\text { diterima }\end{array}$ \\
\hline $\begin{array}{l}\text { Kecerdasan } \\
\text { Spiritual }\left(\mathrm{X}_{3}\right)\end{array}$ & -1.223 & 0.225 & & $\begin{array}{l}\text { Ho diterima dan } \mathrm{Ha} \\
\text { ditolak }\end{array}$ \\
\hline Motivasi $\left(\mathrm{X}_{4}\right)$ & 3.257 & 0.002 & & $\begin{array}{l}\text { Ho ditolak dan } \mathrm{Ha} \\
\text { diterima }\end{array}$ \\
\hline $\begin{array}{l}\text { Interaksi } \\
\text { antara } \\
\text { variabel }\end{array}$ & 0.657 & 0.514 & & $\begin{array}{l}\text { Ho diterima dan } \mathrm{Ha} \\
\text { ditolak }\end{array}$ \\
\hline
\end{tabular}




\begin{tabular}{|l|l|l|l|l|}
\hline \multicolumn{1}{|c|}{ Variabel } & t hitung & Signifikansi & Kriteria Pengujian & Kesimpulan \\
\hline Kecerdasan & & & & \\
Intelektual & & & & \\
dan Motivasi & & & & \\
$\left(\mathrm{X}_{2 \_} \mathrm{X}_{4}\right)$ & & & \\
\hline
\end{tabular}

\section{Sumber : Data diolah}

Hasil uji t menunjukkan bahwa variabel kecerdasan emosional $\left(\mathrm{X}_{1}\right)$, berpengaruh tidak signifikan terhadap pemahaman mahasiswa mahasiswa prodi akuntansi semester 1 dan 3 Universitas Muhammadiyah Surabaya mengenai akuntansi dasar. Hal ini ditunjukkan

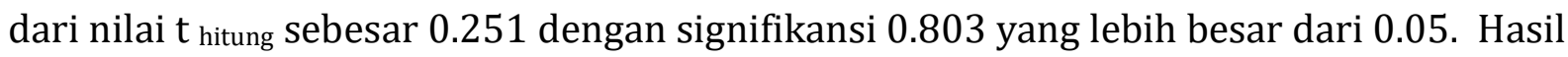
uji t berikutnya menunjukkan bahwa terdapat pengaruh signifikan kecerdasan intelektual $\left(\mathrm{X}_{2}\right)$ terhadap pemahaman akuntansi dasar. Hal tersebut ditunjukkan dari

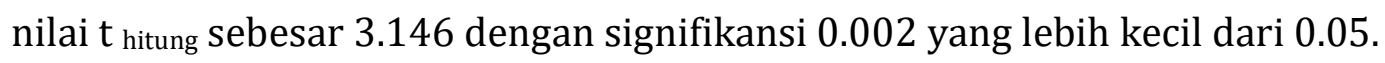

Hasil uji $\mathrm{t}$ juga menunjukkan bahwa variabel kecerdasan spiritual $\left(\mathrm{X}_{3}\right)$, berpengaruh tidak signifikan terhadap pemahaman mahasiswa prodi akuntansi semester 1 dan 3 Universitas Muhammadiyah Surabaya mengenai akuntansi dasar. Hal ini ditunjukkan dari nilai $t$ hitung sebesar -1.223 dengan signifikansi 0.225 yang lebih besar dari 0.05 . Untuk hasil uji t menunjukan pula bahwa motivasi tidak memoderasi pengaruh kecerdasan emosional terhadap pemahaman akuntansi dasar. Hal ini ditunjukan dari dari nilai $t_{\text {hitung }}$ sebesar 0.657 dengan signifikansi 0.514 yang lebih besar dari 0.05. Berdasarkan hasil tersebut maka hipotesis yang menyatakan bahwa motivasi memoderasi pengaruh kecerdasan intelektual terhadap pemahaman akuntansi dasar ditolak. Tetapi dtunjukkan pada tabel diatas bahwa motivasi mempunyai pengaruh terhadap pemahaman akuntansi dasar jika sebagai variabel bebas bukan sebagai

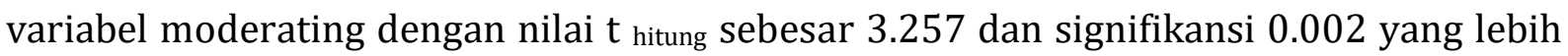
kecil dari 0.05 .

Pengaruh Kecerdasan Spiritual Terhadap Pemahaman Akuntansi Dasar Dengan Motivasi sebagai Variabel Moderating.

Tabel 14.

Hasi uji F (ANOVA)

\begin{tabular}{|l|r|r|r|r|l|}
\hline Sumber varian & \multicolumn{1}{|c|}{$\begin{array}{c}\text { Jumlah } \\
\text { kuadrat }\end{array}$} & \multicolumn{1}{|c|}{ Df } & $\begin{array}{c}\text { Kuadrat } \\
\text { tengah }\end{array}$ & F hitung & Sig. \\
\hline Regresi & 9.874 & 5 & 1.975 & 11.518 & $.000^{\mathrm{b}}$ \\
\hline Sisa & 12.173 & 71 & 0.171 & & \\
\hline Total & 22.047 & 76 & & & \\
\hline
\end{tabular}


Berdasarkan tabel diatas dapat diketahui nilai $\mathrm{F}$ hitung yang diperoleh dari pengolahan data adalah 11.518 dengan tingkat siginifikansi sebesar 0,000 atau lebih kecil 0.05 maka Ho ditolak dengan Ha diterima, yang artinya model yang digunakan adalah signifikan atau cocok untuk mengetahui pengaruh kecerdasan emosional $\left(\mathrm{X}_{1}\right)$, kecerdasan intelektual $\left(\mathrm{X}_{2}\right)$, kecerdasan spiritual $\left(\mathrm{X}_{3}\right)$ dan motivasi $\left(\mathrm{X}_{4}\right)$ terhadap pemahaman akuntansi dasar (Y).

Tabel 15.

Hasil uji t

\begin{tabular}{|c|c|c|c|c|}
\hline Variabel & t hitung & Signifikansi & Kriteria Pengujian & Kesimpulan \\
\hline $\begin{array}{l}\text { Kecerdasan } \\
\text { Emosional } \\
\left(\mathrm{X}_{1}\right)\end{array}$ & 0.186 & 0.853 & \multirow{5}{*}{$\begin{array}{l}\text { Jika nilai probabilitas } \\
\text { (P value)/signifikan > } \\
0.05 \text { maka Ho diterima } \\
\text { dan Ha ditolak } \\
\text { Jika nilai probabilitas } \\
(\mathrm{P} \text { value }) / \text { signifikan < } \\
0.05 \text { maka Ho ditolak } \\
\text { dan Ha diterima }\end{array}$} & $\begin{array}{l}\text { Ho diterima } \\
\text { dan Ha ditolak }\end{array}$ \\
\hline $\begin{array}{l}\text { Kecerdasan } \\
\text { Intelektual } \\
\left(\mathrm{X}_{2}\right)\end{array}$ & 3.105 & 0.003 & & $\begin{array}{l}\text { Ho ditolak dan } \\
\text { Ha diterima }\end{array}$ \\
\hline $\begin{array}{l}\text { Kecerdasan } \\
\text { Spiritual }\left(\mathrm{X}_{3}\right)\end{array}$ & -1.176 & 0.244 & & $\begin{array}{l}\text { Ho diterima } \\
\text { dan Ha ditolak }\end{array}$ \\
\hline Motivasi $\left(\mathrm{X}_{4}\right)$ & 3.283 & 0.002 & & $\begin{array}{l}\text { Ho ditolak dan } \\
\text { Ha diterima }\end{array}$ \\
\hline $\begin{array}{l}\text { Interaksi } \\
\text { antara } \\
\text { variabel } \\
\text { Kecerdasan } \\
\text { Spiritual dan } \\
\text { Motivasi } \\
\left(\mathrm{X}_{3} \mathrm{X}_{4}\right) \\
\end{array}$ & 0.308 & 0.759 & & $\begin{array}{l}\text { Ho diterima } \\
\text { dan Ha ditolak }\end{array}$ \\
\hline
\end{tabular}

\section{Sumber : Data diolah}

Hasil uji t menunjukkan bahwa variabel kecerdasan emosional $\left(\mathrm{X}_{1}\right)$, berpengaruh tidak signifikan terhadap pemahaman mahasiswa mahasiswa prodi akuntansi semester 1 dan 3 Universitas Muhammadiyah Surabaya mengenai akuntansi dasar. Hal ini ditunjukkan

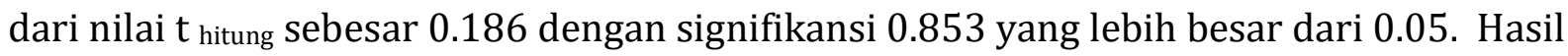
uji $\mathrm{t}$ berikutnya menunjukkan bahwa terdapat pengaruh signifikan kecerdasan intelektual $\left(\mathrm{X}_{2}\right)$ terhadap pemahaman akuntansi dasar. Hal tersebut ditunjukkan dari

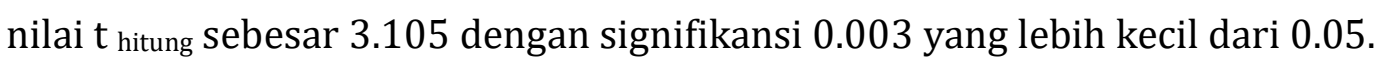

Hasil uji $t$ juga menunjukkan bahwa variabel kecerdasan spiritual $\left(\mathrm{X}_{3}\right)$, berpengaruh tidak signifikan terhadap pemahaman mahasiswa prodi akuntansi semester 1 dan 3 Universitas Muhammadiyah Surabaya mengenai akuntansi dasar. Hal ini ditunjukkan dari nilai $t$ hitung sebesar -1.176 dengan signifikansi 0.244 yang lebih besar dari 0.05. Untuk hasil uji t menunjukan pula bahwa motivasi tidak memoderasi 
pengaruh kecerdasan emosional terhadap pemahaman akuntansi dasar. Hal ini ditunjukan dari dari nilai $t_{\text {hitung }}$ sebesar 0.308 dengan signifikansi 0.759 yang lebih besar dari 0.05. Berdasarkan hasil tersebut maka hipotesis yang menyatakan bahwa motivasi memoderasi pengaruh kecerdasan intelektual terhadap pemahaman akuntansi dasar ditolak. Tetapi dtunjukkan pada tabel diatas bahwa motivasi mempunyai pengaruh terhadap pemahaman akuntansi dasar jika sebagai variabel bebas bukan sebagai variabel moderating dengan nilai $t_{\text {hitung }}$ sebesar 3.283 dan signifikansi 0.002 yang lebih kecil dari 0.05 .

\section{Pembahasan}

Berdasarkan hasil pengujian secara statistik menunjukkan bahwa tidak terdapat pengaruh kecerdasan emosional terhadap pemahaman akuntansi dasar. Tetapi hasil penelitian ini sejalan Widaningrum dkk(2010). Hal ini disebabkan bahwa ternyata kecerdasan emosional saja tidak bisa menjadi satu-satunya faktor yang mempengaruhi pemahaman seseorang terhadap akuntansi dasar. Faktor lain selain kecerdasan emosional dimungkinkan bisa mempengaruhi pemahaman akuntansi dasar misalnya motivasi belajar, perilaku belajar dan minat belajar. Perbedaan dengan penelitian Widaningrum dkk (2010) pada variabel terikat, yaitu pemahaman IFRS. Namun hasil penelitian ini menolak hasil penelitian Rachmi (2010) berpendapat bahwa indikator dalam kecerdasan emosional berpengaruh terhadap tingkat pemahaman akuntansi.

Pada pengujian juga terdapat pengaruh kecerdasan intelektual terhadap pemahaman akuntansi dasar. Hasil penelitian ini sejalan dengan penelitian Zakiah (2013). Tetapi hanya ada perbedaan pada variabel terikat dan sampel yang digunakan, dalam penelitian Zakiah (2013) ditujukan pada pemahaman akuntansi dengan sampel yaitu mahasiswa S1 akuntansi yang sedang menyusun skripsi. Untuk penelitian ini pada pemahaman akuntansi dasar dengan sampel mahasiswa semester 1 dan 3 prodi akuntansi. Hal ini menunjukkan pula bahwa ternyata kecerdasan intelektual saja tidak bisa menjadi satu-satunya faktor yang mempengaruhi pemahaman seseorang terhadap akuntansi dasar. Dan selanjutnya pengujian juga tidak terdapat berpengaruhnya kecerdasan spiritual terhadap pemahaman akuntansi dasar. Hasil penelitian ini sejalan Dwijayanti (2009). Tetapi hanya ada perbedaan pada variabel terikat, dalam penelitian Dwijayanti (2009) ditujukan pada pemahaman akuntansi dengan sampel yaitu mahasiswa S1 akuntansi yang sedang menyusun skripsi. Untuk penelitian ini pada 
pemahaman akuntansi dasar dengan sampel mahasiswa semester 1 dan 3 prodi akuntansi. Hal ini menunjukkan pula bahwa ternyata kecerdasan spiritual saja tidak bisa menjadi satu-satunya faktor yang mempengaruhi tingkat pemahaman seseorang terhadap akuntansi dasar. Faktor lain selain kecerdasan spiritual dimungkinkan bisa mempengaruhi pemahaman akuntansi dasar misalnya kecerdasan sosial.

Hasil uji statistik berikutnya menunjukan bahwa motivasi tidak memoderasi pengaruh kecerdasan emosional terhadap pemahaman akuntansi dasar. Hasil tersebut senada dengan penelitian Widaningrum et.al. (2010). Dalam pengujian analisis dan uji hipotesis yang pertama motivasi mempunyai pengaruh terhadap pemahaman akuntansi dasar sebagai variabel bebas bukan variabel moderating sehingga motivasi dalam penelitian ini memperlemah kecerdasan emosional dalam mempengaruhi pemahaman akuntansi dasar bukan memperkuat.

Berdasarkan uji statistik selanjutnya, motivasi juga tidak memoderasi pengaruh kecerdasan intelektual terhadap pemahaman akuntansi dasar. Hal ini dimungkinkan disebabkan karena motivasi ternyata tidak menjadi satu-satunya faktor yang mempengaruhi kecerdasan intelektual untuk memahami sesuatu, sehingga motivasi dalam penelitian ini juga memperlemah kecerdasan intelektual dalam mempengaruhi pemahaman akuntansi dasar.

Berdasarkan uji statistik selanjutnya, motivasi juga tidak memoderasi pengaruh kecerdasan spiritual terhadap pemahaman akuntansi dasar. Hal ini dimungkinkan disebabkan karena motivasi ternyata tidak menjadi satu-satunya faktor yang mempengaruhi kecerdasan intelektual untuk memahami sesuatu, sehingga motivasi dalam penelitian ini juga memperlemah kecerdasan spiritual dalam mempengaruhi pemahaman akuntansi dasar.

Terdapat faktor lain yang mungkin bisa mempengaruhi pemahaman akuntansi dasar selain kecerdasan emosional dan kecerdasan spiritual misalnya ketersediaan sarana untuk belajar (Widaningrum et.al, 2010), dan perilaku seseorang untuk belajar (Rachmi, 2010) dan kecerdasan sosial (Dwijayanti, 2009). Variabel moderating yang dijadikan penelitian Widaningrum dkk (2010), yaitu minat. Untuk penelitian ini variabel moderating yang digunakan adalah motivasi dan ternyata motivasi tidak memoderasi ketiga variabel bebas yaitu kecerdasan emosional, kecerdasan intelektual dan kecerdasan spiritual dalam mempengaruhi pemahaman akuntansi dasar. Hal tersebut 
bisa disebabkan mahasiswa prodi akuntansi semester 1 dan 3 Universitas Muhammadiyah Surabaya sebagai sampel dalam penelitian ini belum mempunyai motivasi untuk mempelajari akuntansi dasar, dimungkinkan konsep dalam akuntansi dasar tidak begitu penting untuk matakuliah akuntansi selanjutnya bagi mahasiswa prodi akuntansi semester 1 dan 3 Universitas Muhammadiyah Surabaya. Oleh karena itu motivasi untuk mempelajari konsep akuntansi dasar masih belum ada. Untuk itu perlu diketahui bahwa mahasiswa akuntansi semester 1 dan 3 Universitas Muhammadiyah Surabaya bervariasi latar belakang tingkat pendidikan/kelulusan sekolah tingkat menengah atas antara lain SMA -IPA, SMK non akuntansi. Tetapi kemungkinan juga terdapat faktor-faktor yang antara lain karena masih belum ada motivasi memiliki, meminjam buku, browsing internet, kursus akuntansi dasar atau bertanya secara pribadi ke dosen pengampu apabila masih belum mengerti tentang materi yang diajarkan.

\section{Kesimpulan Dan Saran}

\section{Kesimpulan}

Dari hasil penelitian dapat ditarik kesimpulan bahwa kecerdasan emosional dan spiritual berpengaruh tidak signiifikan terhadap pemahaman akuntansi dasar. Hal ini bisa saja disebabkan karena banyak faktor lainnya tidak teramati dalam penelitian ini misalnya tekanan mental, lingkungan pergaulan, trauma kegagalan, masalah pribadi, kegiatan diluar kampus (bekerja), tidak adanya dorongan atau motivasi untuk bertanya jika ada materi atau soal yang belum bisa dimengerti. Untuk kecerdasan intelektual berpengaruh signifikan terhadap pemahaman akuntansi dasar. Kecerdasan intelektual itu sendiri merupakan kemampuan seseorang memperoleh ilmu pengetahuan, dapat menguasai dalam menghadapi masalah yang di alami oleh mahasiswa. Motivasi ternyata tidak memoderasi pengaruh kecerdasan emosional, intelektual dan spiritual terhadap pemahaman akuntansi dasar.

\section{Saran}

Bagi mahasiswa umumnya diharapkan untuk lebih memahami, mempelajari konsep akuntansi dasar dari sumber manapun, antara lain belajar dari buku-buku text book, belajar dari browsing internet, kursus akuntansi dasar atau bertanya secara pribadi pada dosen pengampu matakuliah akuntansi apabila ada materi atau soal yang belum bisa dimengerti, dan lain sebagainya. Untuk penelitian berikutnya seyogyanya 
disarankan agar menambah jumlah sampel yang lebih banyak dan lebih luas lingkupnya, misalnya penelitian juga dilakukan pada Perguruan Tinggi Negeri atau Perguruan Tinggi sejawa timur baik Perguruan Tinggi Negeri maupun Perguruan Tinggi Swasta serta dilakukan wawancara langsung dengan responden.

\section{Daftar Pustaka}

Agustian, Ary Ginanjar. 2007. Emotional Spiritual Quotient The ESQ Way 165. Penerbit Arga Publishing. Jakarta.

Dwijayanti Arie Pangestu. 2009. Pengaruh Kecerdasan Emosional, Kecerdasan Intelektual, Kecerdasan Spiritual dan Kecerdasan Sosial terhadap Pemahaman Akuntansi. Skripsi Mahasiswa S1 Fakultas Ekonomi UPN “Veteran” Jakarta.

Ghozali,Imam. 2013. Aplikasi Analisis Multivariate dengan Program SPSS.Badan Penerbit Undip.

Goleman, Daniel. 2000. Working with Emotional Intelligence. Penerbit Gramedia Pustaka Utama. Jakarta.

Handoko, Hani. 2011. Manajemen Edisi 2. Penerbit BPFE Yogyakarta.

Martani, Dwi, dkk. 2016. Akuntansi Keuangan Menengah Berbasis PSAK Edisi 2 Buku 1. Penerbit Salemba Empat.

Melandy, Rissyo dan Aziza, Nurna. 2006. Pengaruh Kecerdasan Emosional Terhadap Tingkat Pemahaman Akuntansi, Kepercayaan Diri Sebagai Variabel Pemoderasi. Padang. Simposium Nasional Akuntansi IX

Pasek, Nyoman Suadnyana. 2015. Pengaruh Kecerdasan Intelektual pada Pemahaman Akuntansi dengan Kecerdasan Emosi dan Kecerdasan Spiritual sebagai variabel moderasi. Program Magister Prodi Akuntansi Program Pascasarjana Universitas Udayana Denpasar.

Sugiyono. 2012. Metode Penelitian Bisnis. Penerbit CV. Alfabeta Bandung.

Sumarsono. 2007. Metode Penelitian Akuntansi (Beberapa contoh Interpretasi hasil pengolahan data). Penerbit Unesa University Press.

Rachmi, Filia. 2010. Pengaruh Kecerdasan Emosional, Kecerdasan Spiritual dan Perilaku Belajar terhadap Pemahaman Akuntansi, Skripsi Mahasiswa S1 Fakultas Ekonomi Universitas Diponegoro Semarang.

Umar, Husein. 2004. Metode Penelitian Untuk Skripsi dan Tesis Bisnis. Cetakan keenam. Penerbit PT. Raja Grafindo Persada, Jakarta.

Widaningrum dkk. 2010. Pengaruh Ketersediaan Sarana Pendidikan dan Kecerdasan Emosional terhadap Tingkat Pemahaman IFRS dengan Minat sebagai Variabel Moderating di Fakultas Ekonomi UNSOED, Simposium Nasional Akuntansi XIII Purwokerto.

Yuniani, Anggun. 2010. Pengaruh Kecerdasan Emosional terhadap Tingkat Pemahaman Akuntansi, Skripsi Mahasiswa S1 Fakultas Ekonomi Universitas Diponegoro Semarang.

Zakiah, Farah. 2013. Pengaruh Kecerdasan Emosional, Kecerdasan Intelektual dan Kecerdasan Spiritual terhadap Pemahaman Akuntansi (Studi Empiris Mahasiswa 
Jurusan Akuntansi Angkatan 2009 Di Universitas Jember). Skripsi Mahasiswa Jurusan Akuntansi S1 Fakultas Ekonomi Universitas Jember.

http://www.AnneAhira.com, 2010

http://www.gelombangotak.com/Pengertian-Kecerdasan-Spiritual\%20(SQ).htm 
Journal Of Accounting Science Vol. 1 No. 2 EISSN 2548-3501

July

Journal Homepage: http://ojs.umsida.ac.id/index.php/jas

2017 